PRACE NAUKOWE UNIWERSYTETU EKONOMICZNEGO WE WROCLAWIU

\title{
Anna Dubel
}

AGH Akademia Górniczo-Hutnicza

e-mail: adubel@zarz.agh.edu.pl

\section{PORÓWNANIE WYCENY WALORÓW ŚRODOWISKA EKOSYSTEMU BLOŃ KRAKOWSKICH ZA POMOCĄ KILKU WYBRANYCH METOD WYCENY \\ COMPARATIVE ANALYSIS OF METHODS OF ENVIRONMENTAL VAULATION. CASE STUDY OF BLONIA KRAKOWSKIE}

DOI: $10.15611 / \mathrm{pn} .2017 .478 .11$

JEL Classification: Q51, Q57

Streszczenie: Błonia krakowskie są obszarem o uznanych walorach kulturowych i przyrodniczych, mających znaczenie nie tylko dla miasta i jego mieszkańców, lecz również milionów turystów odwiedzających miasto corocznie. Celem badań przedstawionych w artykule było porównanie wyceny walorów tego ekosystemu, z uwzględnieniem usług ekosystemowych, za pomocą kilku wybranych metod wyceny środowiska, takich jak: metoda wyceny warunkowej poprzez określenie WTP i WTA, metoda cen hedonicznych, metoda kosztów podróży i metody kosztowe. Zaprezentowano wyniki implementacji tych metod do wyceny usług ekosystemu krakowskich Błoń. Przeanalizowano rezultaty pod kątem przyczyn zaobserwowanych rozbieżności w otrzymanych wartościach wyceny. Przedstawiono uzyskane wartości na tle wyników zgromadzonych na podstawie przeglądu literatury w zakresie analizowanych metod wyceny. Wnioski zawierają rekomendacje dotyczące implementacji tych metod.

Słowa kluczowe: środowisko, wycena, metody, Błonia krakowskie, WTP, WTA.

Summary: Błonia Krakowskie is an area of recognized natural and cultural values, which are important not only for the city and its residents, but also for tourists sightseeing the place. The aim of the research presented in the paper is to compare the ecosystem values/evaluation methods and outcomes, including ecosystem services, obtained using several selected environmental valuation methods, such as contingent valuation method (defining the WTP and WTA), hedonic pricing method, travel costs method and other cost methods. The results of the implementation of these methods for the valuation of Błonia Krakowskie ecosystem is presented. The results are analysed in terms of the causes of the observed differences in the values obtained in valuation. The conclusions also contain recommendations concerning the implementation of these valuation methods.

Keywords: environment, valuation, methods, WTP, WTA, Błonia Krakowskie. 


\section{Wstęp}

Przypisywanie wartości pieniężnych zasobom środowiska naturalnego wydaje się niepotrzebne lub etycznie wątpliwe. $Z$ drugiej strony decydenci oczekują, iż analiza ekonomiczna będzie wpierać procesy podejmowania decyzji i przyczyni się do ochrony zasobów [MEA 2005]. Dyskusja na ten temat toczy się w literaturze naukowej od wielu lat [McCauley 2006; Costanza i in. 2014; Kronenberg 2015]. Równocześnie metody wyceny środowiska nie doczekały się powszechnego włączenia $\mathrm{w}$ procesy podejmowania decyzji z uwagi na brak ufności decydentów w precyzję ich wyników wynikającą z ich niedoskonałości, w tym błędów systematycznych i statystycznych [Folmer i in. 1996]. Wycena pieniężna zmierzająca do ustalenia całkowitej wartości ekonomicznej (Total Economic Value) stanowi jednak jedynie ułamek całkowitej wartości wycenianego zasobu środowiska, w tym ekosystemu, gdyż w niedoskonałym stopniu jesteśmy w stanie zinwentaryzować zasoby, określić ich znaczenie w kontekście użyteczności oraz przypisać tym nierynkowym dobrom wartość pieniężną. Ponadto wyceny często pomijają wartość przyrodzoną [Folmer $i$ in. 1996]. W procesie wyceny przyjmowany jest szereg szczególnych założeń, które utrudniają uniwersalizację wycen, tak iż oszacowane wartości mają znaczenie jedynie jako studia przypadków i ograniczają możliwość transferu. Rozwijane są równocześnie metody transferu korzyści [Atkison 2007; Brouwer 2000].

Celem badań przedstawionych $\mathrm{w}$ artykule było porównanie wyceny walorów ekosystemu Błoń krakowskich, z uwzględnieniem usług ekosystemowych, przeprowadzonej za pomocą kilku wybranych metod wyceny środowiska, takich jak: metoda wyceny warunkowej poprzez określenie WTP i WTA, metoda cen hedonicznych, metoda kosztów podróży i metody kosztowe. W szczególności porównano wartości otrzymane w wyniku wycen dokonywanych różnymi metodami oraz zinterpretowano je w świetle przyjętych założeń. W punkcie 2 omówiono wybrane metody, ich założenia oraz sposób przeprowadzenia badań. Następnie scharakteryzowano obszar badawczy, jakim były Błonia krakowskie. Zaprezentowano wyniki implementacji metod do wyceny usług ekosystemu Błoń oraz przeprowadzono ich dyskusję $\mathrm{w}$ świetle innych badań tego typu przedstawionych w literaturze przedmiotu.

Naukowe i praktyczne znaczenie przeprowadzonych badań polega na poznaniu wartości ekonomicznej analizowanego zasobu środowiska i szacunkowego wyrażenia jej w pieniądzu. Wiedza ta może pozwolić na lepsze planowanie finansowe oraz budżetowanie i wydatkowanie środków publicznych w mieście i regionie, dzięki poznaniu preferencji mieszkańców odnośnie do sposobów korzystania z analizowanego zasobu oraz poznaniu znaczenia funkcji, jakie pełni ten ekosystem dla mieszkańców aglomeracji krakowskiej.

Chciałam serdecznie podziękować studentom II roku studiów licencjackich kierunku zarządzanie na Wydziale Zarządzania Akademii Górniczo-Hutniczej w roku akademickim 2015/2016 za zaangażowanie w przeprowadzenie badań dotyczących wyceny ekosystemu Błoń krakowskich. 


\section{Metody badawcze}

W artykule przedstawiono analizę porównawczą wybranych metod wyceny środowiska zaimplementowanych do wyceny usług ekosystemu krakowskich Błoń. Do badania wybrano zarówno metody odkrywania preferencji (hipotetyczne, bezpośrednie), takie jak metoda wyceny warunkowej, jak i metody rynkowe (pośrednie), takie jak: metoda kosztów podróży, metoda cen hedonicznych (wykorzystujące rynki zastępcze), czy metody kosztowe (wykorzystujące rynki konwencjonalne). Metody rynkowe oparte są na obserwacji faktycznych wyborów dokonywanych przez konsumentów na rynku i ustaleniu związku pomiędzy popytem na nie a podażą dóbr środowiskowych. Porównano metody pod względem następujących aspektów:

- wartości wyceny i ich rozstęp,

- wrażliwości uzyskanych wyników na przyjęte szczegółowe założenia,

- stopnia przydatności uzyskanych wyników dla decydentów.

Wskazane powyżej zagadnienia dotyczą kwalifikowalności tych metod do ich uwzględnienia jako wiarygodne źródło wiedzy w procesach podejmowania decyzji. Przeprowadzone badania pozwalają na określenie preferencji respondentów odnośnie do sposobu wykorzystania przestrzeni miejskiej.

Celem przeprowadzonych różnymi metodami badań i analiz była wycena usług ekosystemu Błoń krakowskich. Wyceniano ekosystem jako całość z uwagi na fakt, iż ekosystemy świadczą wiele usług jednocześnie, których „dostępność zależy od funkcjonowania ekosystemu jako całości składającej się z wielu zależnych od siebie elementów" [Kronenberg 2012].

Pozyskano łącznie odpowiedzi od 1440 respondentów badań ankietowych, co stanowiło 0,19\% całkowitej liczby mieszkańców Krakowa w 2015 r. Badania przeprowadzono w maju 2015 r. w okolicach Błoń. Respondentów dobierano losowo spośród osób przebywających na Błoniach i w okolicy. Przeprowadzenie badania składało się z następujących kroków:

- Opracowanie kwestionariusza badawczego lub innej metody analizy pod kątem weryfikacji założonych hipotez.

- Przeprowadzenie badania.

- Analiza wyników.

Poniżej krótko scharakteryzowano analizowane metody, przedstawiono sposób, $\mathrm{w}$ jaki przeprowadzono badania, oraz istotne spostrzeżenia.

\subsection{Metoda kosztów podróży}

Metoda kosztów podróży (TCM, Travel Cost Method) służy do szacowania wartości zasobów środowiska w danym miejscu (insitu). Konsumenci ,ujawniają swoją wycenę dobra środowiska poprzez faktyczną konsumpcję, w tym przypadku poprzez wydatki związane z podróżą" [Folmer i in. 1996]. Wartość ekonomiczna jest wyli- 
czana na podstawie wartości poświęconego czasu (utracona płaca), kosztów dojazdu, kosztów opłat ponoszonych na miejscu. W przeprowadzonym badaniu poza pozyskaniem tych informacji od respondentów zwrócono uwagę na odległość ich miejsca zamieszkania od Błoń oraz czy pobyt na Błoniach był ich głównym celem, czy był realizowany przy okazji wizyty w innym miejscu.

\subsection{Metoda cen hedonicznych}

Metoda cen hedonicznych (HPM, Hedonic Price Method) polega na „określaniu w jednostkach pieniężnych korzyści uzyskiwanych dzięki usługom środowiska, poprzez ocenę wpływu tych usług na ceny związanych z nimi dóbr i usług" [Folmer $i$ in. 1996]. Metoda zakłada zdekomponowanie ceny dobra rynkowego, powiązanego z analizowanym dobrem środowiska (np. ceny nieruchomości), na sumę atrybutów charakteryzujących dobro rynkowe, pośród których będzie analizowane dobro środowiska. Szacowana funkcja ceny hedonicznej pozwala na obserwacje zmian cen nieruchomości, przy zmianie poziomu analizowanego dobra środowiskowego, ceteris paribus. Przedstawione w tabeli 1 wyniki wyrażają różnice cen nieruchomości ze względu na odległość od Błoń.

Plan badania zakładał dokonanie segmentacji rynku nieruchomości na różne rodzaje nieruchomości (mieszkania, apartamenty, domy, w tym różne segmenty ze względu na metraż) i analizę cen ofertowych nieruchomości w różnej odległości od Błoń. Wzięto również pod uwagę możliwość substytucji usług ekosystemu Błoń przez usługi innych parków miejskich w Krakowie. W analizie przyjęto następujące hipotezy, które zostały zweryfikowane pozytywnie:

- Błonia krakowskie są walorem wykazywanym w ofertach nieruchomości.

- Ceny nieruchomości w okolicach Błoń są wyższe niż ceny podobnych nieruchomości w dalszej odległości od Błoń.

\subsection{Metoda wyceny warunkowej poprzez określenie gotowości do zapłaty (WTP)}

Metoda wyceny warunkowej (CVM, Contingent Valuation Method) polega na bezpośrednim pozyskaniu od respondentów informacji o ich gotowości do zapłaty za dane dobro środowiska (WTP, Willingness to Pay) lub (WTA, Willingness to Accept) [Bjornstad, Kahn (eds.) 1996].

W badaniu respondenci wskazywali również pożądane i preferowane przez nich ulepszenia dotyczące Błoń, wśród których najczęściej wskazywana były poprawa infrastruktury (kosze na śmieci, ławki, nawierzchnia) oraz upiększenia, w szczególności nasadzenia kwiatowe. 


\subsection{Metoda wyceny warunkowej poprzez określenie gotowości do przyjęcia rekompensaty (WTA)}

Gotowość do przyjęcia rekompensaty analizowana była analogicznie, jak w przypadku WTP. Najważniejszym pytaniem ankiety, po rozmowie nt. cennych walorów Błoń, było pytanie o wysokość rekompensaty dla respondenta za utratę możliwości korzystania z Błoń.

\subsection{Metoda kosztów odtworzenia}

Metoda odtworzeniowa (RM, Restoration Method) jest jedną z metod kosztowych, w której wycena jest dokonywana na podstawie wartości kosztów działań, podejmowanych aby odnowić lub zrekultywować zasób środowiska, przywracając mu jego pierwotną wartość.

Wyceny dokonano na podstawie cen rynkowych (ofertowych) na usługi w zakresie odtworzenia zasobów, takich jak: trawa, drzewa, usługi równania terenu.

\subsection{Metoda utraconych możliwości}

Metoda utraconych możliwości (OCM, Opportunity Cost Method) jest jedną z metod kosztowych. Szacuje ona wartość użytkowanych dóbr i zasobów środowiska na podstawie dochodów z alternatywnych, zaniechanych wariantów ich użytkowania.

Wybrane warianty wpływają korzystnie na poprawę większości usług ekosystemu Błoń.

\section{Studium przypadku}

Błonia krakowskie, przestawione na rysunku 1, to park miejski o charakterze rozległej łąki o powierzchni ok. 48 ha, czyli 12 razy większy od Rynku Głównego i prawie 2 razy większy od sumarycznej powierzchni Rynku Głównego (4 ha) i Plant (21 ha). Na przestrzeni wieków Błonia pełniły dla mieszkańców Krakowa rozmaite funkcje. Ponad 3,5-kilometrowy obwód Błoń wiele osób codziennie pokonuje, biegając, spacerując, jeżdżąc na rowerze czy też na rolkach. Można stwierdzić, iż jest to bardzo popularne wśród mieszkańców Krakowa miejsce rekreacji, często wykorzystywane do organizacji imprez masowych, takich jak koncerty. Błonia położone są w pobliżu sprzyjającego rekreacji parku Jordana oraz w niedalekiej odległości od jednego z najsłynniejszych i zabytkowych punktów widokowych Krakowa - kopca Kościuszki. Są one ograniczone uczęszczanymi arteriami komunikacyjnymi, alejami Focha i 3 Maja oraz ulicą Piastowską, a także wałami rzeki Rudawy (rys. 2). Ulice te są poszerzone o szerokie aleje spacerowe wraz ze ścieżkami rowerowymi, które są tłumnie odwiedzane głównie przez mieszkańców Krakowa i okolic, zwłaszcza w weekendy. Bliskość Rynku Głównego czyni Błonia atrakcyjnym miejscem 


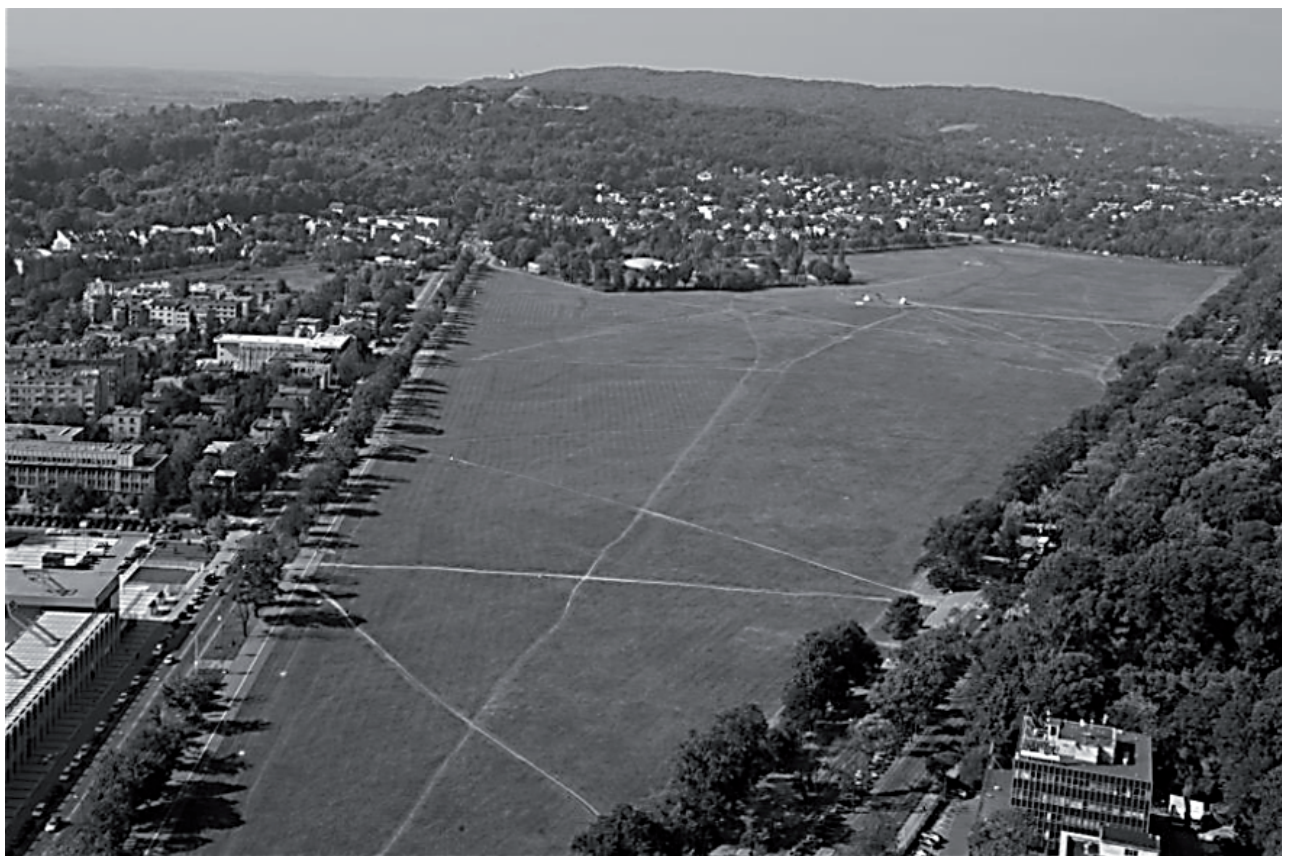

Rys. 1. Błonia krakowskie z lotu ptaka

Źródło: zasoby miasta Krakowa.

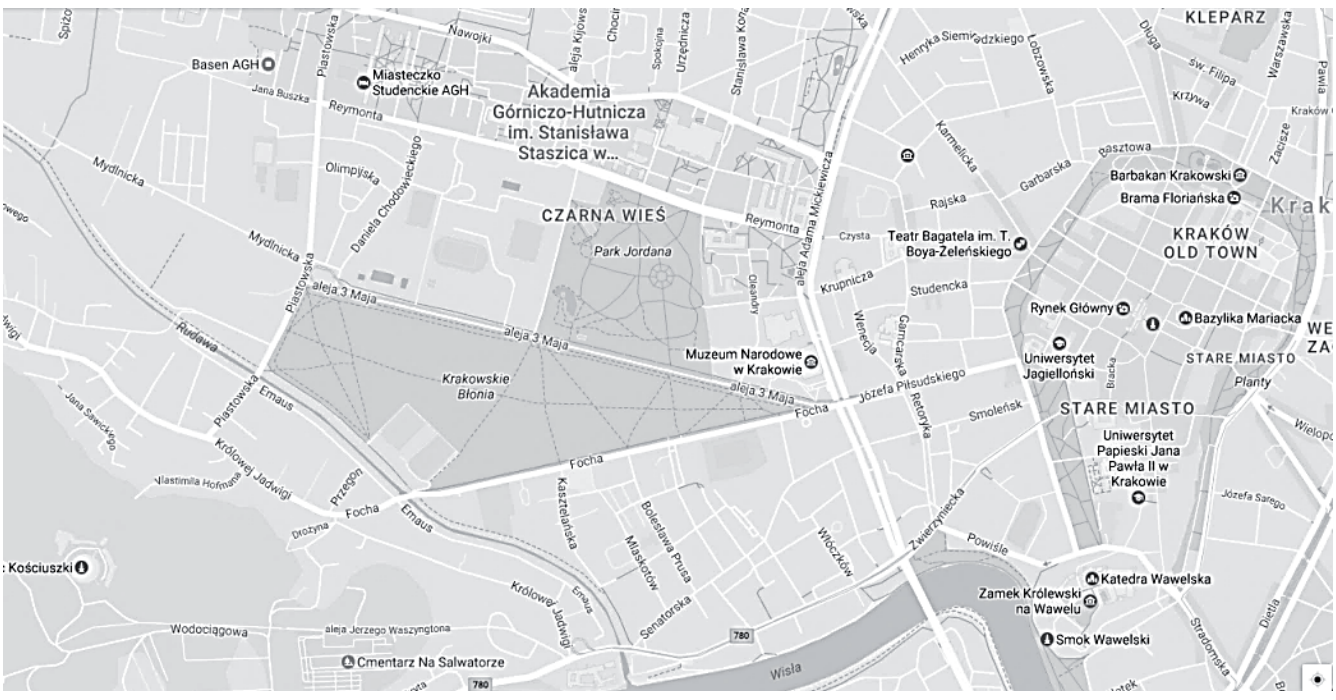

Rys. 2. Błonia krakowskie i okolice

Źródło: Google Maps. 
spacerowym również dla turystów. Ze względu na swoje rozmiary jest to też ważna przestrzeń poprawiająca przewietrzanie miasta, które bardzo często zmaga się ze smogiem. Zabudowa okolic Błoń to głównie budownictwo jednorodzinne oraz budynki użyteczności publicznej, jak Muzeum Narodowe, stadiony klubów sportowych „Cracovia” i „Wisła”. Jak widać na rysunku 1, przez łąkę prowadzą utarte ścieżki, jest to miejsce wykorzystywane do spacerów, natomiast nie rozwinęły się tradycje piknikowe, jak w parkach zachodniej Europy.

Historia Błoń krakowskich [Bąkowski 1908] sięga XII w., kiedy to łąka stała się własnością klasztoru norbertanek z Krakowa. W XIV w. siostry przekazały miastu działkę, która była wykorzystywana jako pastwisko miejskie. Do XIX w. przez Błonia przepływała obecnie uregulowana i obwałowana rzeka Rudawa. Na początku XX w. dokonano ostatecznych prac melioracyjnych: osuszono bagna, założono deptak oraz zbudowano przepusty odprowadzające wodę. Od XI w. Błonia pełniły funkcję reprezentacyjną, urządzano tam oficjalne uroczystości, spotkania Ojca Świętego z wiernymi, parady, koncerty etc. W 1997 r. Błonia uchwałą Rady Miasta Krakowa Nr LXX/694/97 zyskały status parku miejskiego, który „służy do wypoczynku oraz aktywnej rekreacji w miejscach do tego przeznaczonych".

Ekosystem Błoń krakowskich to siedlisko łąkowe, równinna łąka otoczona od północy potrójną linią starodrzewu (jesiony i lipy), liczącego wzdłuż alei 3 Maja 485 sztuk drzew, a od południa młodym szpalerem z ponad 200 okazami drzew [Marcinek 1999]. Bazując na podstawowych kategoriach usług ekosystemów [MEA 2005, TEEB 2010], takich jak usługi: zaopatrujące, siedliskowe, regulacyjne czy kulturowe, w przeprowadzonych ankietach wstępnie predefiniowano usługi ekosystemu Błoń jako:

- możliwość uprawiania sportów i rekreacji,

- obcowanie z przyrodą w centrum miasta,

- miejsce spotkań i imprez,

- miejsce, które może zagospodarować wodę w przypadku powodzi,

- pozytywny wpływ na jakość powietrza w Krakowie,

- miejsce do życia dla roślin i zwierząt,

- jedyna taka łąka w środku miasta w Europie,

- zachowanie Błoń dla przyszłych pokoleń.

Poniżej przedstawiono porównanie wyników analizowanych metod wyceny.

\section{Porównanie wyników wybranych metod wyceny}

W tabeli 1 zebrano wyniki dotyczące wartości przypisywanym Błoniom. Wyniki charakteryzują się dużym rozstępem, nawet do 100\% deklarowanych wartości, który w każdej z metod wynika z różnych przyczyn. Przykładowo, w metodzie kosztu podróży wartości zerowe deklarowały osoby chodzące pieszo na Błonia, nie ponoszące dodatkowych wydatków na miejscu i nie pracujące. W metodach wyceny warunkowej natomiast ujawnia się zagadnienie ,jazdy na gapę”. 
Tabela 1. Wyniki szacowania wartości ekosystemu Błoń krakowskich za pomocą różnych metod wyceny środowiska

\begin{tabular}{|l|c|c|c|c|c|c|}
\hline & $\begin{array}{c}\text { TCM } \\
\text { (PLN/ } \\
\text { m-c/os.) }\end{array}$ & $\begin{array}{c}\text { HPM } \\
(\text { PLN/m²) }\end{array}$ & $\begin{array}{c}\text { CVM WTP } \\
\text { (PLN/ } \\
\text { m-c/os.) }\end{array}$ & $\begin{array}{c}\text { CVM WTA } \\
\text { (PLN/ } \\
\text { m-c/os. })\end{array}$ & $\begin{array}{c}\text { RM } \\
\text { (tys. PLN) }\end{array}$ & $\begin{array}{c}\text { OCM } \\
\text { (tys. PLN) }\end{array}$ \\
\hline Wartość max & 250 & 3000 & 300 & 25 & 1000 & 2000 \\
\hline Wartość min & 0 & 1411 & 0 & 0 & 12 & 1500 \\
\hline Wartość średnia & 20,20 & 1982 & 13,80 & 8,57 & 254 & 1750 \\
\hline Mediana & 16,43 & 1500 & 5 & 9 & 184 & 1750 \\
\hline Rozstęp & 250 & 1589 & 300 & 25 & 988 & 500 \\
\hline
\end{tabular}

* TCM - metoda kosztów podróży, HPM - metoda cen hedonicznych, CVM WTP - metoda wyceny warunkowej z określeniem gotowości do zapłaty, CVM WTA - metody wyceny warunkowej z określeniem gotowości do przyjęcia rekompensaty, RM - metoda kosztów odtworzenia, OCM - metoda utraconych możliwości.

Źródło: opracowanie własne na podstawie przeprowadzonych badań.

Różnice w otrzymanych wartościach wyceny są rezultatem tego, iż w metodach rynkowych oszacowane zostały wartości różnych dóbr rynkowych, które są w relacji do wycenianego ekosystemu. Natomiast przy wycenie warunkowej wskazane wartości przybliżają postrzeganą przez respondentów wartość dóbr środowiska, która może zawierać również korzyści pozaużytkowe. Ponadto każdy z wyników należy interpretować w kontekście przyjętych założeń oraz ograniczeń danej metody, które zostały zebrane w publikacji [Folmer i in. 1996].

Najczęściej wymienianym walorem ekosystemu Błoń krakowskich, który cenią respondenci, była możliwość uprawiania sportów i rekreacji, następnie były one doceniane jako miejsce spotkań i imprez oraz obcowania z przyrodą. Równocześnie największą grupę ankietowanych stanowiły osoby w przedziale wieku 19-20 lat, a kolejną pod względem liczebności grupą były osoby w wieku 25-30 lat. Natomiast struktura próby według płci jest adekwatna do struktury populacji.

Między wzrostem ceny mieszkań a odległością od Błoń zaobserwowano słabą ujemną korelację. Średnia wartość współczynnika korelacji Pearsona dla wszystkich analizowanych segmentów wyniosła 0,34 .

Analiza danych z metryczek w badaniach ankietowych wskazuje, iż starsi respondenci przypisywali wyższe wartości pieniężne do ekosystemu i znacznie częściej zwracali uwagę na znaczenie Błoń dla przyszłych pokoleń.

Przy okazji implementacji metody kosztów odtworzenia można zauważyć, iż wartości wyceny w wysokim stopniu zależą od sposobu zniszczenia zasobu, np. powódź, wichura, oraz skali zdarzenia i powstałych szkód, co przekłada się na sposób, w jaki przeprowadzane jest odtworzenie ekosystemu oraz na różne poziomy możliwej realizacji wskazanych usług ekosystemów w wariantach zdefiniowanych przez odmienne sposoby odtwarzania. Podobnie w metodzie utraconych możliwości wartość wyceny zależy od wartości i zyskowności planowanych inwestycji. 
Analizowane metody badania preferencji i wyborów dokonywanych przez konsumentów ekosystemu Błoń, w przeważającej mierze mieszkańców Krakowa i okolic, z pewnością nie uwzględniają wartości ekologicznej ekosystemu (np. znaczenia bioróżnorodności), jak postuluje Fromm [2000], a jedynie jego znacznie dla ludzi.

$\mathrm{W}$ efekcie zastosowania analizowanych metod otrzymujemy szerokie spektrum wartości, dlatego ważny jest precyzyjny dobór metody do celu badania. Obiecujące wyniki daje metoda modelowania wyboru (Choice Modelling), w której respondenci ustalają ranking alternatyw i dokonują wyboru pomiędzy nimi [Brouwer i in. 2013].

W badaniach wystąpiły dobrze rozpoznane i opisane w literaturze przedmiotu problemy [Bateman, Willis (eds.) 1999; Folmer i in. 1996], takie jak:

- trudności respondentów w udzieleniu odpowiedzi na złożone pytania wielokrotnego wyboru,

- pozyskiwane od respondentów wartości pieniężne są wrażliwe na sposób przeprowadzania badania oraz kolejność i sformułowanie zadawanych pytań.

\section{Zakończenie}

Do najważniejszych wniosków z przeprowadzonego badania należą:

- Wyniki są wrażliwe na przyjęte szczegółowe założenia, w szczególności wartości wyceny otrzymywane w metodach kosztowych są bardzo wrażliwe na hipotetyczne warianty zakładane przy sporządzaniu wyceny.

- Wyniki mogą mieć znaczenie dla decydentów nie jako oszacowane wartości ekonomiczne dla określenia ceny sprzedaży Błoń, np. pod zabudowę, lecz jako wyrażenie preferencji mieszkańców oraz znaczenia, jakie dla nich ma ta śródmiejska łąka.

- Pozyskane informacje mogą uzupełniać analizy finansowe i ekonomiczne, jak analiza efektywności kosztowej czy analiza kosztów i korzyści, a także analizy wielowymiarowe i wielokryterialne, służące do oceny wariantów planowanych rozwiązań (zmian w zagospodarowaniu przestrzennym, lokowania inwestycji), o informacje dotyczące deklarowanych preferencji.

- Istotne są też informacje pozyskiwane w procesach wyceny, inne niż szacowana wartość ekosystemu, takie jak pożądane i preferowane społecznie ulepszenia dotyczące Błoń czy preferowane lub akceptowalne społecznie warianty inwestycji alternatywnych.

Rekomendacją dla implementacji metod wyceny jest konieczność precyzyjnego określenia celu badania i dobór najbardziej właściwej metody, z katalogu metod wyceny środowiska, dla uzyskania pożądanego efektu lub uzyskania potrzebnych informacji. 


\section{Literatura}

Atkinson G., 2006, Environmental valuation and benefits transfer, [w:] Florio M. (ed.), Cost-Benefit Analysis and Incentives in Evaluation. The Structural Funds of the European Union, Edward Elgar Publishing, Cheltenham, UK.

Bateman I.J., Mace G.M., Fezzi C., Atkinson G., Turner K., 2011, Economic analysis for ecosystem service assessment, Environmental and Resource Economics, vol. 48, s. 177-218.

Bateman I.J., Willis K.G. (eds.), 1999, Valuing Environmental Preferences, Oxford University Press, Oxford.

Bąkowski K., 1908, Przechadzka historyczna po błoniach, Kraków.

Bjornstad D.J., Kahn J.R. (eds.), 1996, The Contingent Valuation of Environmental Resources, Edward Elgar, Cheltenham.

Brouwer R., 2000, Environmental Value Transfer: State of the art and future prospects, Ecological Economics, no. 32, s. 137-152.

Brouwer R., Brander L., Kuik O., Papyrakis E. and Bateman I., 2013, A synthesis of approaches to assess and value ecosystem services in the EU in the context of TEEB. TEEB follow-up study for Europe, VU Institute for Environmental Studies.

Constanza R. i in., 1997, The Value of the World's Ecosystem Services and Nature Capital, Nature, no. 387 , s. $253-260$.

Costanza R., de Groot R., Sutton P., van der Ploeg S., Anderson S.J., Kubiszewski I., Farber S., Turner R.K., 2014, Changes in the global value of ecosystem services, Global Environmental Change, no. 26 , s. $152-158$.

Folmer H., Gabel L., Opschoor H., 1996, Ekonomia środowiska i zasobów naturalnych, Wydawnictwo Krupski i S-ka, Warszawa.

Fromm O., 2000, Ecological Structure and Functions of Biodiversity as Element of Its Total Economic Value, Environmental Resources Economics, no. 16, s. 303-328.

Garrod G., Willis K.G., 1999, Economic Valuation of the Environment, Edward Elgar, Cheltenham, UK, Northhampton, MA, USA.

Kronenberg J., 2015, Betting against Human Ingenuity: The Perils of the Economic Valuation of Nature's Services, BioScience, no. 65 (11), s. 1096-1099.

Kronenberg J., 2012, Ustugi ekosystemów w miastach, Zrównoważony Rozwój - Zastosowania, nr 3.

Marcinek R., 1999, Z dziejów Błoń krakowskich, Teka Komisji Urbanistyki i Architektury PAN, Kraków, t. XXXI, s. 7-24.

McCauley D.J., 2006, Selling out on nature, Nature, no. 443, s. 27-28.

MEA, 2005, Millenium Ecosystem Assessment. Ecosystems and Human Well-Being: Synthesis, Island Press.

Sartori D. (red.), 2014, Przewodnik po analizie kosztów i korzyści projektów inwestycyjnych. Narzędzie analizy ekonomicznej polityki spójności 2014-2020, Komisja Europejska, Bruksela.

TEEB, 2010, The Economics of Ecosystems and Biodiversity Ecological and Economic Foundations, Edited by Pushpam Kumar, Earthscan, London-Washington. 